\title{
A pheromone-independent CarR protein controls carbapenem antibiotic synthesis in the opportunistic human pathogen Serratia marcescens
}

\footnotetext{
1 Department of Biochemistry, University of Cambridge, Tennis Court Road, Cambridge CB2 1QW, UK

2 Department of Pharmaceutical Sciences, University of Nottingham, Nottingham NG7 2RD, UK

3 Department of Applied Biochemistry and Food Sciences, University of Nottingham Faculty of Agriculture and Food Sciences, Sutton Bonington LE12 5RD, UK
}

\author{
A. R. J. Cox, ${ }^{1}$ N. R. Thomson, ${ }^{1}$ B. Bycroft, ${ }^{2}$ G. S. A. B. Stewart, ${ }^{3}$ P. Williams ${ }^{2}$ \\ and G. P. C. Salmond ${ }^{1}$
}

Author for correspondence: G. P. C. Salmond. Tel: +441223 333650. Fax: +441223 333345. e-mail: gpcs@mole.bio.cam.ac.uk

\begin{abstract}
Strain ATCC 39006 of Serratia marcescens makes the same carbapenem, (5R)carbapen-2-em-3-carboxylic acid (Car), as the Erwinia carotovora strain GS101. Unlike E. carotovora, where the onset of production occurs in the lateexponential phase of growth in response to the accumulation of the small diffusible pheromone $\mathbf{N}$-(3-oxohexanoyl)-L-homoserine lactone (OHHL), in S. marcescens carbapenem is produced throughout the growth phase and does not appear to involve any diffusible pheromone molecule. Two cosmids capable of restoring antibiotic production in E. carotovora group I carbapenem mutants were isolated from an $\mathrm{S}$. marcescens gene library. These cosmids were shown to contain a homologue of the $E$. carotovora carR gene, encoding a CarR protein with homology to the LuxR family of transcriptional regulators. The $S$. marcescens carR was subcloned and shown to be capable of complementing in trans, in the absence of OHHL, an E. carotovora carR carl double mutant, releasing the heterologous $E$. carotovora host from pheromone dependence for carbapenem production. The apparent $\mathrm{OHHL}$-independence of the $S$. marcescens CarR explains the constitutive nature of carbapenem production in this strain of $S$. marcescens.
\end{abstract}

Keywords: Serratia marcescens, carbapenem, $\beta$-lactam, $N$-acylhomoserine lactone, LuxR homologue

\section{INTRODUCTION}

Carbapenems are $\beta$-lactam antibiotics, discovered in the 1970 s through a mass screening of micro-organisms for new antibiotics (Sykes et al., 1981; Imada et al., 1981). They have a clinical potential that lies in their potent, broad spectrum activity against both Gram-positive and Gram-negative bacteria (Kropp et al., 1980, 1985) as well as resistance to a wide range of $\beta$-lactamases (Kahan et al., 1983; Labia et al., 1986). Many of the 40 or so naturally occurring carbapenems that have so far been identified are produced by Streptomyces spp., and radiolabelling studies on thienamycin production by Streptomyces cattleya (Williamson, 1986) have shown

Abbreviations: Car, (5R)-carbapen-2-em-3-carboxylic acid; OHHL, $\mathrm{N}$-(3oxohexanoyl)-L-homoserine lactone.

The GenBank accession number for the sequence reported in this paper is AF012907. that carbapenems are produced by a biosynthetic pathway quite different from that used for penicillins and cephalosporins. However, the slow growth and poor genetic tractability of many of the carbapenemproducing organisms has hindered molecular genetic studies of the synthesis of carbapenem and the regulation of its production. Consequently all therapeutically useful carbapenems are, at present, made by total chemical synthesis.

The mass screening of different bacteria revealed that the parent carbapenem, (5R)-carbapen-2-em-3-carboxylic acid (Car), is produced by strains of two fastgrowing, genetically amenable Gram-negative bacteria : Serratia marcescens and Erwinia carotovora (Parker et al., 1982). This carbapenem is easily detected by a simple plate bioassay employing a sensitive strain of Escherichia coli. In contrast to the more complex situation found in Streptomyces this simple carbapenem appears to be the only antibiotic produced by $S$. marcescens and 
E. carotovora, although $S$. marcescens does also produce the red pigment prodigiosin (Morrison, 1966) which is structurally related to the antibiotic undecylprodigiosin produced by Streptomyces ceolicolor and Streptomyces lividans (Tsao et al., 1985; Hopwood et al., 1995). Although E. carotovora and S. marcescens both produce the same antibiotic, in $S$. marcescens carbapenem is produced throughout the growth phase (Bycroft et al., 1988), whereas in E. carotovora carbapenem production is that of a classical secondary metabolite with the onset of production occurring in the late-exponential phase of growth (Bainton et al., 1992b). It was hoped that investigating carbapenem production in both E. carotovora and $S$. marcescens might uncover similarities in the biosynthetic pathway and differences between the regulatory mechanisms.

It had previously been shown that $E$. carotovora mutants deficient in the production of carbapenem could be divided into two groups, group 1 and group 2, and that carbapenem activity could be restored to the group 2 mutants by cross-feeding of supernatants from the group 1 mutants. Group 2 mutants are defective in the carl gene, which encodes a protein responsible for the synthesis of the small, diffusible pheromone $\mathrm{N}$-(3oxohexanoyl)-L-homoserine lactone (OHHL), which was found to be excreted by the group 1 mutants and by the wild-type (Bainton et al., 1992a, b). In E. carotovora strain GS101, OHHL is required to induce the synthesis of carbapenem and the synthesis of multiple exoenzyme virulence factors (pectinases, cellulases and proteases) (Jones et al., 1993). Consequently, the group 2 mutants have a pleiotropic, $\mathrm{Car}^{-}$(Carbapenem production) and $\operatorname{Rex}^{-}$(Regulation of exoenzymes) mutant phenotype. This pleiotropy is abolished by the addition of OHHL, either exogenously or through cross-feeding, or by the provision of the carl gene in trans. Although some of the group 1 mutants were originally presumed to be defective in carbapenem biosynthesis (car) genes a number of them have been shown to be defective in the carR gene, which encodes a putative transcriptional regulator of the car genes, CarR (McGowan et al., 1995). The group 1 CarR mutants can be complemented for carbapenem production by the provision of the carR gene in trans. CarR, the function of which is OHHLdependent under normal physiological conditions, exhibits homology to the Vibrio fischeri transcriptional regulator, LuxR, and joins the rapidly growing family of LuxR homologues which control a variety of phenotypes in several different bacterial genera (Salmond et al., 1995).

Most of the regulators in the LuxR family exert their control in a cell-density-dependent manner and, as with E. carotovora CarR, many of them are known to, or are predicted to, act in concert with OHHL or similar diffusible $\mathrm{N}$-acylhomoserine lactones. In this process (now known as quorum sensing) it appears that availability of a threshold concentration of the pheromone is responsible for initiating significant gene expression, presumably by binding to and activating the appropriate transcriptional regulator. In Agrobacterium tumefaciens cell-density-dependent expression of the tra genes, which are involved in the conjugal transfer of the $\mathrm{Ti}$ plasmid, is regulated by $\operatorname{luxI} / R$ homologues, traI and traR, and involves the pheromone, $\mathrm{N}$-3-(oxo-octanoyl)L-homoserine lactone (Zhang et al., 1993; Piper et al., 1993). In the human pathogen Pseudomonas aeruginosa, a LuxR homologue, LasR, acts as a positive transcriptional regulator for the expression of lasB (Gambello et al., 1991), which is responsible for the production of elastase, a major virulence determinant of this organism. A luxI homologue, lasI, is necessary for the production of the pheromone $\mathrm{N}$-3-(oxo-dodecanoyl)-L-homoserine lactone (Passador et al., 1993; Pearson et al., 1994), which is thought to activate the LasR protein. In Pseudomonas aureofaciens the phenazine antibiotic genes are transcriptionally regulated by a LuxR homologue, PhzR (Pierson, 1994), in response to the accumulation of a pheromone produced by $p h z I$ (Wood \& Pierson, 1996). In Erwinia stewartii pathogenicity is effected by capsular polysaccharide, the biosynthetic genes for which are transcriptionally controlled by the product of the esaR gene, EsaR. OHHL, resulting from expression of the esal gene, is required as the pheromone (Beck von Bodman \& Farrand, 1995). In Rhizobium leguminosarum the LuxR homologue RhiR exerts positive transcriptional control over the rbiABC operon (Cubo et al., 1992). However, there are LuxR homologues, such as SdiA in Escherichia coli, which specifically increases transcription of the fts $Q A Z$ cell division gene cluster (Wang et al., 1991), for which no specific pheromone molecule has yet been associated.

In this report we describe the isolation and identification of an $S$. marcescens carR gene, encoding a LuxR homologue, CarR, which appears to function in a pheromone-independent fashion and so is capable of constitutively activating carbapenem synthesis in $S$. marcescens. The $S$. marcescens CarR is also capable of releasing a heterologous $E$. carotovora host from pheromone dependency for carbapenem production.

\section{METHODS}

Bacterial strains and media. Strains, plasmids and phages used in this study are listed in Table 1 . Erwinia carotovora and Serratia marcescens strains were routinely grown at $30^{\circ} \mathrm{C}$; Escherichia coli was grown at $37^{\circ} \mathrm{C}$. The E. coli ESS bioassay was carried out at $25^{\circ} \mathrm{C}$. LB medium (Miller, 1972) was used with $\mathrm{OHHL}$ supplements added where required, to a final concentration of $1 \mu \mathrm{g} \mathrm{ml}^{-1}$

Isolation of S. marcescens carbapenem cosmids by direct, 2mediated cosmid complementation. Chromosomal DNA of the wild-type $S$. marcescens strain ATCC 39006 was prepared and partially digested with Sau3A, size-fractionated and then ligated with BamHI-digested DNA of cosmid vector pSF6 (Selvaraj et al., 1984). The ligation mixture was packaged into coliphage $\lambda$ heads in vitro using the Giga pack gold II kit (Stratagene). The packaged $\lambda$ cosmid library was used to infect E. carotovora group $1 \mathrm{Car}^{-}$mutants carrying the $\mathrm{LamB}$ plasmid pTroy9 (see Ellard et al., 1989) and cosmid-containing transductants were selected on LB agar plates containing spectinomycin at $50 \mu \mathrm{g} \mathrm{ml}^{-1}$. The transductants were screened for restoration of carbapenem production using the halo 
Table 1. Strains, plasmids and phages used in this study

\begin{tabular}{|c|c|c|}
\hline Strain/plasmid/phage & Characteristics & Reference \\
\hline \multicolumn{3}{|l|}{$\begin{array}{l}\text { Strain } \\
\text { Escherichia coli } \mathrm{K}-12\end{array}$} \\
\hline ESS & $\beta$-Lactam super-sensitive & Bainton et al. (1992a) \\
\hline DH1 & $\begin{array}{l}\mathrm{F}^{-} \operatorname{supE} 44 \operatorname{rec} A 1 \text { endA1 gyrA96 }\left(\mathrm{Nal}^{\mathrm{r}}\right) \text { thi-1 hsdR17 }\left(\mathrm{r}_{\mathrm{k}}^{-} \mathrm{m}_{\mathrm{k}}^{+}\right) \\
\text {relA1 }\end{array}$ & Hanahan (1983) \\
\hline \multicolumn{3}{|l|}{$\begin{array}{l}\text { Erwinia carotovora } \\
\text { subsp. carotovora }\end{array}$} \\
\hline ATCC 39048 & Wild-type $\left(\mathrm{Car}^{+}\right)$ & Bainton et al. (1992a) \\
\hline GS101 & ATCC 39048(pTROY9)::Tn5 restrictionless & Bainton et al. (1992a) \\
\hline ATTN10 & ATCC 39048:: $\operatorname{Tn} 10$ restrictionless $\left(\operatorname{Tn} 10\right.$ cured $\left.\mathrm{Tc}^{\mathrm{s}}\right)$ & McGowan et al. (1996) \\
\hline PNP11 & GS101 carR & McGowan et al. (1995) \\
\hline PNP14 & GS101 carR & McGowan et al. (1995) \\
\hline TCR5 & ATTN10 carR:: Tn5 & This study \\
\hline PNP21 & GS101 $\mathrm{Car}^{-}$ & McGowan et al. (1995) \\
\hline PNP22 & GS101 carI & McGowan et al. (1995) \\
\hline PNP23 & GS101 carI & McGowan et al. (1995) \\
\hline PRTX1 & ATTN10 carl::TnphoA'2 & This study \\
\hline TCRI 51 & TCR5 carl :: TnphoA'2 & This study \\
\hline \multicolumn{3}{|l|}{ Serratia marcescens } \\
\hline ATCC 39006 & Wild-type $\left(\mathrm{Car}^{+}\right)$ & Bycroft et al. (1988) \\
\hline SC13 & ATCC 39006 (pMUT13) & This study \\
\hline SC9 & ATCC 39006 (pTROY9) & This study \\
\hline WT1 & SC9 $\mathrm{Pig}^{-}$ & This study \\
\hline WM5 & SC13 Pig- & This study \\
\hline CWT11 & WT1 Car ${ }^{-}$ & This study \\
\hline CWT12 & WT1 Car ${ }^{-}$ & This study \\
\hline CWT13 & WT1 Car ${ }^{-}$ & This study \\
\hline CWT14 & WT1 Car ${ }^{-}$ & This study \\
\hline CWT15 & WT1 Car ${ }^{-}$ & This study \\
\hline CWT18 & WT1 Car ${ }^{-}$ & This study \\
\hline CWT31 & WT1 Car ${ }^{-}$ & This study \\
\hline CWM52 & WM5 Car- & This study \\
\hline \multicolumn{3}{|l|}{ Plasmids } \\
\hline pSF6 & Low-copy-number mobilizable cosmid cloning vector & Selvaraj et al. (1984) \\
\hline pNRT1 & $\mathrm{pSF} 6$, car $^{+}$(S. marcescens $)$ & This study \\
\hline pNRT20 & pSF6, $\operatorname{car}^{+}(S$. marcescens $)$ & This study \\
\hline cWU142 & pSF6, car $^{+}$(E. carotovora) & McGowan et al. (1995) \\
\hline pWU14203 & pSF6 (cWU142 carR ${ }^{+}$subclone) & McGowan et al. (1995) \\
\hline pTON28 & pSF6 (pNRT1 carR ${ }^{+}$subclone) & This study \\
\hline pDAH330 & High-copy-number (pIC19R derived) cloning vector & Unpublished results \\
\hline pTON28M & pDAH330 (pNRT1 carR $^{+}$subclone) & This study \\
\hline pT7-5 & $\mathrm{T} 7 \phi 10$ promoter & Tabor \& Richardson $(1985)$ \\
\hline pT7-15 & pT7-5 (pNRT1 carR ${ }^{+}$subclone) & This study \\
\hline \multicolumn{3}{|l|}{ Phages } \\
\hline \multicolumn{3}{|l|}{ Coliphages } \\
\hline M13 mp18 & DNA sequencing vector & Messing et al. (1977) \\
\hline$\lambda \mathrm{cI} 857^{2}$ & Thermoinducible & Vollenweider et al. (1980) \\
\hline$\lambda:: \operatorname{Tn} 5-\mathrm{B} 20$ & Carries Tn5-lacZ & Krebs \& Reznikoff (1988) \\
\hline$\lambda:: T n p h o A^{\prime}-2$ & Carries $\operatorname{Tn} 10-l a c Z$ & Wilmes-Riesenberg \& Wanner (1992) \\
\hline \multicolumn{3}{|l|}{ E. carotovora phages } \\
\hline$\phi \mathrm{KP}$ & E. carotovora generalized transducing phage & Toth et al. (1993) \\
\hline
\end{tabular}

bioassay test with $E$. coli ESS as described by Bainton $\boldsymbol{e t}$ al. (1992b). Complementing cosmids were isolated and used to transform $E$. coli DH1 by electroporation. High-titre $\lambda$ cI857 lysates were raised on the transformants by the method of White et al. (1983) to efficiently package the cosmid DNA and generate high-frequency transducing lysates for these cosmids. 
The lysates were used to transduce various LamB-containing $\mathrm{Car}^{-}$mutants of $E$. carotovora and $S$. marcescens using spectinomycin resistance $\left(\mathrm{Sp}^{\mathrm{r}}\right)$ as the selectable marker. The general aspects of LamB-based cloning and complementation strategies are described elsewhere (Mulholland \& Salmond, 1995).

Southern blot hybridization and subcloning. Southern blots were carried out on Bam $\mathrm{HI}$ restriction digests of $S$. marcescens cosmids pNRT1 and pNRT20 which had been subjected to agarose gel electrophoresis. The agarose gels were photographed with a scale before the DNA was transferred and immobilized on nitrocellulose filters. Filters were blotted at $65^{\circ} \mathrm{C}$ with a ${ }^{32} \mathrm{P}$-labelled probe made from the $E$. carotovora carR subclone pWU14032, then washed in SSC and visualized by autoradiography. A partial Bam $\mathrm{HI}$ digest was used to construct an initial restriction map of the $S$. marcescens cosmids pNRT1 and pNRT20 (Fig. 1). The $2.8 \mathrm{~kb} \mathrm{BamHI}$ fragment of pNRT1 was cloned into the BamHI site of both pSF6 and pDAH330 (a chloramphenicol-resistant derivative of pIC19R; D. Hodgson, personal communication) to yield the subclones pTON28 $\left(\mathrm{Sp}^{\mathrm{r}}\right)$ and pTON28M $\left(\mathrm{Cm}^{\mathrm{r}}\right)$ respectively. These subclones were transferred into various $\mathrm{Car}^{-}$ mutants of $E$. carotovora and $S$. marcescens by electroporation, using spectinomycin and chloramphenicol resistance as the selectable markers.

Sequence analysis. Random subclones, ligated into M13mp18, were generated from the insert DNA of pTON28 by the ligation and sonication method described by Bankier $e t$ al. (1986). The subclones were sequenced by the dideoxynucleotide chain-termination procedure (Sanger et al., 1977) using a Sequenase kit (USB).

Gene product identification. A $3.4 \mathrm{~kb}$ Sall-PstI fragment derived from pNRT1 and containing the $S$. marcescens carR gene was ligated into pT7-5 also digested with SalI and PstI. The resulting plasmid (pT7-15) was used to express the $S$. marcescens carR by the methods described by Tabor $\&$ Richardson (1985). Protein products were separated by SDSPAGE and visualized after autoradiography.

Isolation of S. marcescens carbapenem mutants. Work done on carbapenem non-producing strains of $S$. marcescens had revealed that the prodigiosin pigment produced by $S$. marcescens had a slight anti-bacterial effect on the sensitive $E$. coli strain used in the carbapenem bioassy. Therefore, a $\mathrm{Pig}^{-}$ derivative of the ATCC 39006 strain was used for the isolation of $S$. marcescens carbapenem mutants by chemical mutagenesis. Chemical mutagenesis, performed using EMS, was adapted from the protocol described by Forbes \& Perombelon (1985).

Construction of an E. carotovora carR carl double mutant. A lysate was made on E. carotovora carl mutant PRTX1 (Tcr) using the $\phi \mathrm{KP}$ generalized transducing phage (Toth et al., 1993). This lysate was used to infect $E$. carotovora carR mutant TCR5 $\left(\mathrm{Kn}^{\mathrm{r}}\right)$. An E. carotovora carR carl double mutant, TCRI51, was isolated by selecting transductants on $\mathrm{LB}$ agar plates containing both tetracycline at $10 \mu \mathrm{g} \mathrm{ml}^{-1}$ and kanamycin at $50 \mu \mathrm{g} \mathrm{ml}^{-1}$.

\section{RESULTS AND DISCUSSION}

\section{Complementation of the E. carotovora group I carbapenem mutants}

The screening of $750 \mathrm{Sp}^{\mathrm{r}}$ colonies resulting from the transduction of the $S$. marcescens cosmid gene library
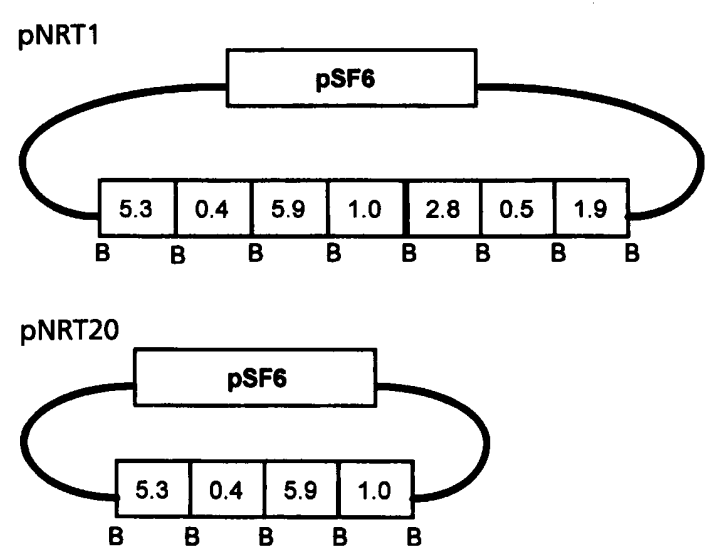

Fig. 1. A schematic map of BamHI (B) restriction enzyme sites present in the $S$. marcescens cosmids pNRT1 and pNRT20. The size, in $\mathrm{kb}$, of the individual fragments is indicated. Both cosmids, due to BamHI/Sau3A ligation, have an indeterminate amount of $S$. marcescens DNA linked to the pSF6 vector DNA.

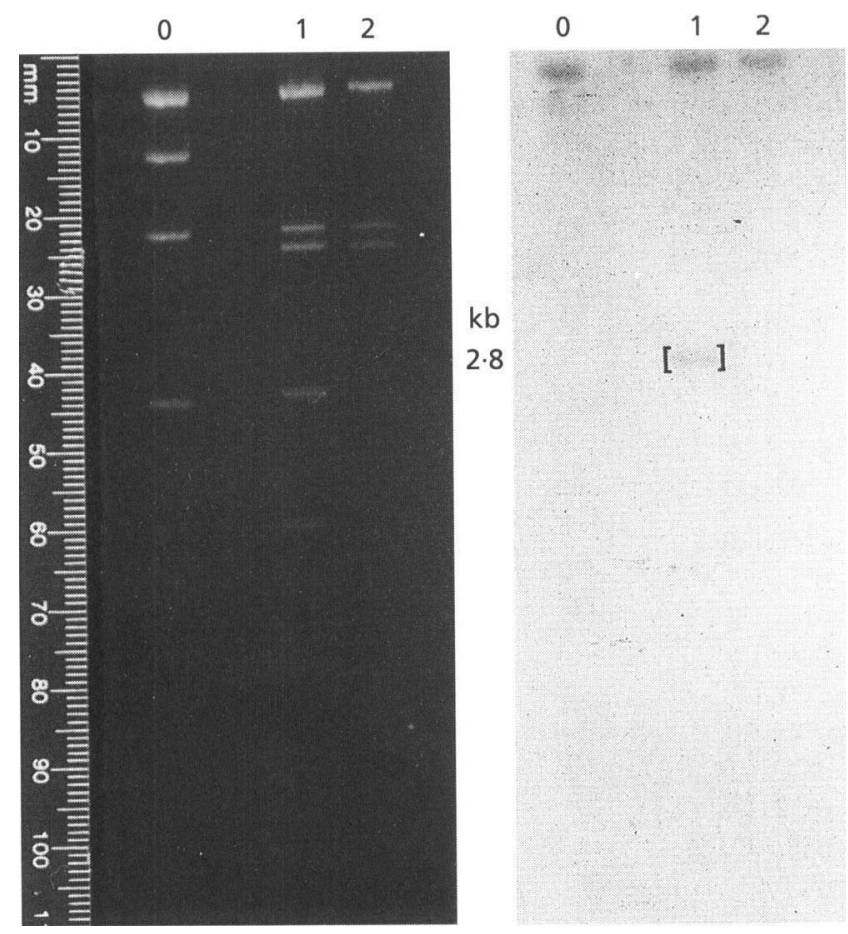

Fig. 2. A Southern blot, of BamHI restriction digests, of the $S$. marcescens cosmids pNRT1 (lane 1) and pNRT20 (lane 2), and the $E$. carotovora cosmid cWU142 (lane 0 ), using the $E$. carotovora carR subclone pWU14203 as a probe. The non-vector homology exhibited by the $2.8 \mathrm{~kb} \mathrm{BamHl}$ fragment of pNRT1 is indicated.

into E. carotovora group I carbapenem mutants PNP1 and PNP20 revealed two cosmids, pNRT1 and pNRT20, capable of restoring antibiotic production in the respective mutants. A restriction map (Fig. 1) was con- 


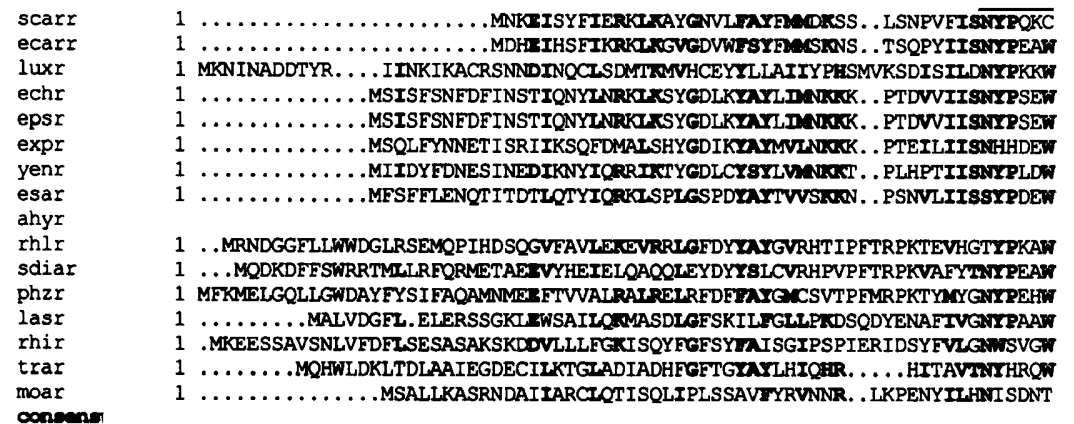

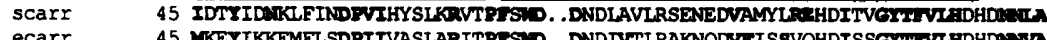

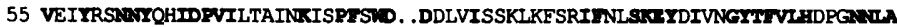

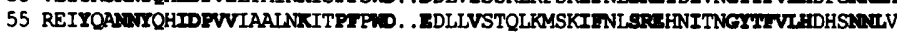

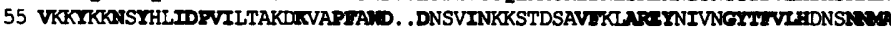

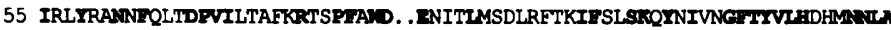

64 VQAYTANHMLACDPIIOLARKOTLPIYYNRLDERARFLOEGSLDVMGLAAEIELRNGISFPIBGAAGENG

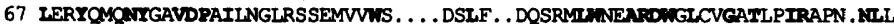

68 VSYYOAKUILAIDEVINPENFSQGHIMEN. . . . DDLF. . SEAQPLITEARRAHGLRRGVHSVENAAQTGAL

71 LQRYQAALTALIDPTVKHSKVSSAPILNS. . . . NEIF. . RNCPDINSENNDSSLCHGLAQPSENTQ.GRV

61 REHYDRAGLARVDPTVSHCTQSVIPIFM. . . . PSTYQTRKQHEFTEEASAAGLVYGLTMPTHGARGEIO

70 FDRYRENITVHADPTVHLSKTCDHATW WEALRDQKL. DRQSRRVMDEARLTKLIDETSVPLITAAGFQS

58 QSTYFDKKIEAIDFVVKRARSRKHI TWSGEHERPTISKDE. RAFYDHASDIGIRSGITIP INTANGENS

54 HOQYLE. SEQPIDPHLPAHFSEQST . . . TMAAMT PRLCDRNRHYYHETMLPNNVRDMTEI FTRRERRIV

scarr

ecarr

luxr

echr

epsr

expr

yenr

esar

ahyr

sdiar

phzi

lasr

rhir

trar

moar

consensuse

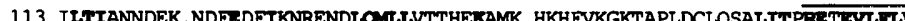
113 ILTIANNDEK. NDFEDFIKNRENDLOWLVTTHEKAMK. HKHFVKGKTAPLDCLQSAIITPRETEVLVV 135 MLSFAHSEKDNYIDSLFWHACMNI PLIVPSLVDN. . . YR . . . . . . KINIANNKSNNDITKREKECI ANA

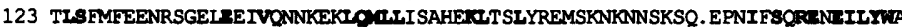

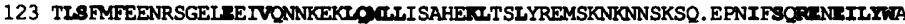
123 MLSIMIDESNVSNIDDVIISNKDKI CIIMTIHAETISLYREMIRNKEDERSN. DKDIFSORENLIITA 123 TUNSNGSDDSISFDERIIINKEKICONIITHENCGLYQSNSDKNENRNTQIERDIFBPRENLIIXA 123 IISVIIKGNDQTAL QRIAAEQGTMG TIIIDFNEOMRIAGTEGERAPALNQSADKTIF8SRANIEVITA 134 ILSFITAERAS. . SDLLIISSPILSW

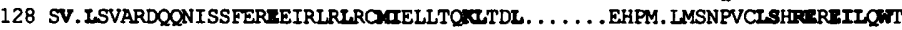

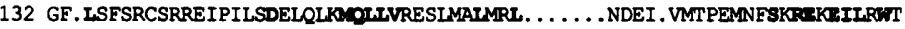

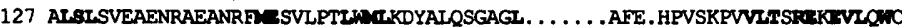
139 IVBFGAEKVELSTC. . . . DRSALYIMAAYAHSLIRAQIG. . . . . . . NDASRKIQALPMCITTRAREIIHWC 127 META. . . SDKPVIDLDR IDAVAAAATIGQIHARISEL. . . . . . . RTTPTAEDAACVDPA ATYIRGI

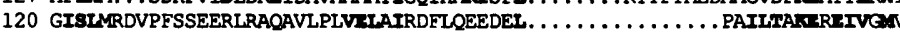

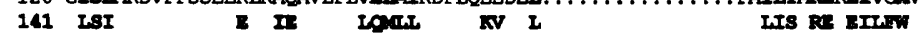

scarr ecarr
Fig. 3. Alignments of the predicted amino acid sequences of (S)CarR (S. marcescens; this work), (E)CarR (E. carotovora; MCGowan et al., 1995; accession no. U17224), LuxR ( $V$. fischeri; Gray \& Greenberg, 1992; accession no. M96844), EchR (E. chrysanthemi; accession no. U45854), EspR ( $P$. solanacearum; accession no. M61197), ExpR (E. carotovora; accession no. X80457), YenR (Y. enterocolitica; Throup et al., 1995; accession no. X76082), EsaR (E. stewartii; Beck von Bodman \& Farrand, 1995; accession no. L32184), AhyR (A. hydrophila; accession no. X89469), RhIR ( $P$. aeruginosa; Oschner et al., 1994; accession no. L08962), SdiA (E. coli; Wang et al., 1991; accession no. P07026), PhzR (P. fluorescens; Pierson et al., 1994; accession no. L32729), LasR ( $P$. aeruginosa; Gambello \& Iglewski, 1991; accession no. M59425), RhiR ( $R$. leguminosarum; Cubo et al., 1992; accession no. M98835), TraR (A. tumefaciens; Zhang et al., 1993; accession no. P33909), MoaR (E. aerogenes; Azakami et al., 1993; accession no. D49928). Positions with eight or more similar residues have been highlighted and indicated as a consensus sequence. The proposed autoinducer binding region and the DNA binding region (regions I and II respectively) are indicated. structed for both cosmids and showed that pNRT20 was effectively a subclone of pNRT1. Both cosmids were transferred into various chemically induced $E$. carotovora $\mathrm{Car}^{-}$mutants and were shown to complement both carR and putative car biosynthetic mutants. This suggested that both pNRT1 and pNRT20 might contain at least some of the $S$. marcescens genes necessary for carbapenem biosynthesis in addition to a homologue of the E. carotovora carR gene.

\section{Subcloning and cross-hybridization of the pNRT1 and PNRT20 cosmids}

Complementation of E. carotovora group I carbapenem mutants by the two $S$. marcescens cosmids pNRT1 and pNRT20 was identical to the complementation achieved with the E. carotovora cosmid cWU142, which was known to contain the $E$. carotovora carR gene and has recently been shown to contain the $E$. carotovora car 
biosynthetic genes (McGowan et al., 1996). This suggested that the carbapenem genes of E. carotovora and $S$. marcescens might be functionally conserved and might also have significant sequence homology.

A Southern blot hybridization was carried out using the E. carotovora carR subclone pWU14203 as the probe (Fig. 2). Non-vector homology was observed in the $2.8 \mathrm{~kb}$ Bam HI fragment of pNRT1. Any similar homology in pNRT20 is masked by vector homology due to the attachment of this region of DNA to the vector in this cosmid.

This $2.8 \mathrm{~kb}$ BamHI fragment of pNRT1 was subcloned back into the low-copy-number vector pSF6 to give pTON28 $\left(\mathrm{Sp}^{\mathrm{r}}\right)$ and into the high-copy-number vector pDAH330 to give pTON28m $\left(\mathrm{Cm}^{\mathrm{r}}\right)$. Both plasmids complemented all the E. carotovora CarR mutants (Table 2) but failed to complement the putative $E$. carotovora Car biosynthetic mutants.

\section{Sequence analysis of the pTON28 subclone}

Analysis of the sequence data revealed a complete ORF of $735 \mathrm{bp}$, with a potential ribosome-binding site and a putative start site for transcription with homology to the -10 and -35 consensus of the Escherichia coli promoter. This ORF showed significant DNA homology to the Erwinia carotovora carR gene $(62.3 \%)$ and was predicted to encode a $28 \cdot 216 \mathrm{kDa}$ protein of 244 amino acids. The predicted protein had strong sequence identity with the predicted $E$. carotovora CarR protein $(59.3 \%$; similarity $72.0 \%)$ and was therefore also designated CarR. As with E. carotovora CarR, the $S$. marcescens CarR had significant similarity to the Vibrio fischeri transcriptional activator LuxR and other members of the LuxR family of transcriptional regulators (Fuqua et al., 1994) (Fig. 3). The sequence identity between the CarR proteins and these transcriptional regulators is particularly strong in the carboxy-terminal putative DNA-binding domain (Choi et al., 1991, 1992), consistent with the model that the CarR proteins act as DNA-binding proteins which are transcriptional regulators of the car biosynthetic genes. There is also strong identity in the putative autoinducer binding domain (Adar et al., 1992). This was expected in the E. carotovora CarR, as carbapenem production in $E$. carotovora is known to be cell-density-dependent and involves OHHL (Bainton et al., 1992b), but is perhaps more surprising in $S$. marcescens CarR, as carbapenem production in this strain of $S$. marcescens is independent of growth phase and does not appear to involve any diffusible pheromone molecule in this strain (unpublished data).

\section{Identification of the S. marcescens CarR protein}

Using $\left[{ }^{35} \mathrm{~S}\right]$ methionine labelling in the $\mathrm{T} 7$ expression system, a protein of approximately $28 \mathrm{kDa}$ was identified (Fig. 4). This corresponds well to the size of $28.216 \mathrm{kDa}$ predicted for the $S$. marcescens CarR from the sequence data.

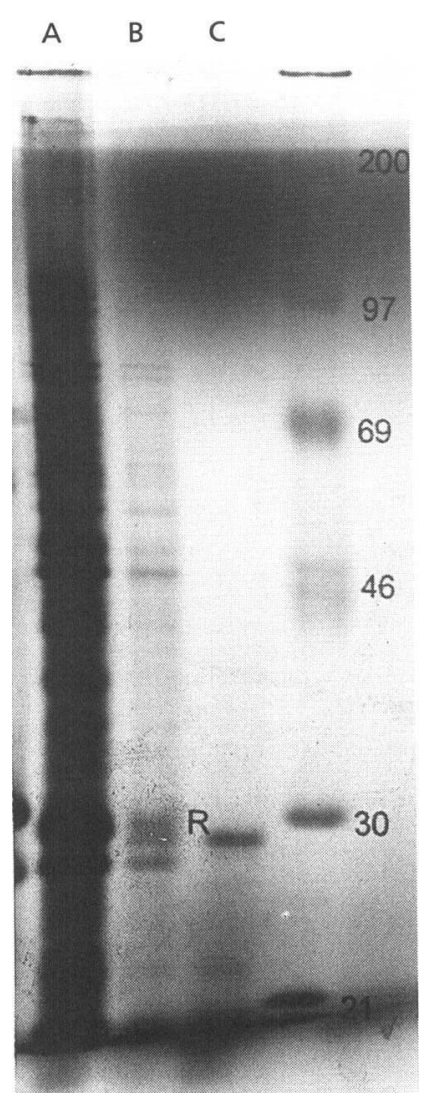

Fig. 4. Identification of CarR in a T7 expression system. A $3.4 \mathrm{~kb}$ fragment carrying carR was cloned into PT7-5 in the correct orientation for expression of carR (pT7-15). Lane A, $30^{\circ} \mathrm{C}$; lane B, $42{ }^{\circ} \mathrm{C}$; lane $\mathrm{C}, 42{ }^{\circ} \mathrm{C}$ +rifampicin (final conen $200 \mu \mathrm{g} \mathrm{ml}^{-1}$ ). Molecular size markers $(\mathrm{kDa})$ are indicated in the right-hand lane. In the presence of rifampicin only one major protein of approximately $28 \mathrm{kDa}$ was labelled (marked $R$ in lane C).

\section{Evidence of $\mathrm{OHHL}$-independent function of the $S$. marcescens CarR}

A number of $S$. marcescens carbapenem non-producing mutants were isolated by chemical mutagenesis of WT1 and WM5 Pig- derivatives of the ATCC 39006 strain. All of these mutants were complemented for antibiotic production by the pNRT1 and pNRT20 cosmids (again suggesting that both these cosmids might contain some of the genes necessary for carbapenem production). The carR subclones pTON28 and pTON28m restored carbapenem production to two of these mutants (Table 2), CWT12 and CWM52, indicating that these were probably CarR mutants. Unlike E. carotovora (Bainton et al., 1992b) the $S$. marcescens $\mathrm{Car}^{-}$mutants could not be divided into different cross-feeding groups and the addition of exogenous OHHL did not restore carbapenem activity or have any other observable phenotypic effect on any of the $S$. marcescens $\mathrm{Car}^{-}$mutants.

Having previously been shown to complement the $E$. carotovora group 1 CarR mutants, the $S$. marcescens carR subclones were transferred into E. carotovora group $2\left(\mathrm{CarI}^{-}\right)$mutants, PNP22 and PNP23 (Table 2), 
Table 2. Complementation analysis of various $S$. marcescens and $E$. carotovora $\mathrm{Car}^{-}$mutants by the carR genes of $S$. marcescens and $E$. carotovora

All strains were tested for the restoration of wild-type carbapenem production $(+)$ as indicated by a $5-6 \mathrm{~mm}$ zone of clearing when spotted onto a lawn of super-sensitive Escherichia coli. Less than wild-type levels of carbapenem production are shown by halo size in parentheses.

\begin{tabular}{|c|c|c|c|c|c|}
\hline \multirow[t]{2}{*}{ Strain/mutant } & \multicolumn{5}{|c|}{$\begin{array}{l}\text { Effect on carbapenem production of complementation with plasmids/ } \\
\text { addition of exogenous OHHL }\end{array}$} \\
\hline & $+\mathrm{OHHL}$ & pWU14203 & $\begin{array}{c}\text { pWU14203+ } \\
\text { OHHL }\end{array}$ & pTON28 & pTON28m \\
\hline PNP11 & NT & + & NT & + & + \\
\hline PNP14 & NT & + & NT & + & + \\
\hline PNP21 & NT & - & NT & - & - \\
\hline CWT11* & NT & NT & NT & - & - \\
\hline CWT12 & NT & NT & NT & + & + \\
\hline CWT13* & NT & NT & NT & - & - \\
\hline CWT14* & NT & NT & NT & - & - \\
\hline CWT15* & NT & NT & NT & - & - \\
\hline CWT18* & NT & NT & NT & - & - \\
\hline CWT31* & NT & NT & NT & - & - \\
\hline CWM52 & NT & NT & NT & + & + \\
\hline PNP22 & + & - & NT & $+(1-2 \mathrm{~mm})$ & $+(3-4 \mathrm{~mm})$ \\
\hline PNP23 & + & - & NT & $+(1-2 \mathrm{~mm})$ & $+(3-4 \mathrm{~mm})$ \\
\hline TCRI51 & - & - & + & + & + \\
\hline
\end{tabular}

NT, Not tested.

* Putative Car biosynthetic mutant.

which do not produce OHHL and consequently have a pleiotropic phenotype which includes the inability to make carbapenem and the down-regulation of exoenzyme synthesis (Jones et al., 1993). The introduction of the $S$. marcescens carR subclones restored some antibiotic activity to these mutants. A low level of antibiotic activity was achieved with the low-copynumber subclone pTON28. The high-copy-number subclone pTON $28 \mathrm{~m}$ restored a higher level of antibiotic activity, but this was still less than in the wild-type strain. The effect of the $S$. marcescens CarR appears to be specific for carbapenem as neither subclone had any observable effect on exoenzyme synthesis (data not shown). It is possible that in the absence of OHHL the E. carotovora CarR may even partially inhibit transcription of the E. carotovora carbapenem genes. The $E$. carotovora group 2 mutants still have a wild-type copy of the E. carotovora carR gene (resulting in the production of $E$. carotovora CarR, the OHHL-dependent transcriptional activator of the $E$. carotovora carbapenem genes; McGowan et al., 1995). Therefore, it was reasoned that the copy-number-dependent complementation observed with the $S$. marcescens carR in $E$. carotovora group 2 mutants, in the absence of OHHL, might be explained by competition between the OHHLdependent E. carotovora CarR and the OHHL-independent $S$. marcescens CarR for a DNA-binding site. To test this hypothesis an $E$. carotovora carR carl double mutant, TCRI51, was constructed. The E. carotovora
carR subclone pWU14203 was transferred into this carR carl double mutant (Table 2). Carbapenem activity was not restored until exogenous OHHL was also added. When the low-copy-number $S$. marcescens carR subclone pTON28 was transferred into this carR carI double mutant (Table 2) carbapenem activity was restored to wild-type levels without the need for the addition of OHHL. It was also noted that carbapenem production was detectable at an earlier stage in the growth curve in the recombinant strain than in the wildtype $E$. carotovora strain (data not shown). The $S$. marcescens CarR appears to be capable of acting as a functional replacement for the mutant $E$. carotovora CarR without the need for OHHL. The wild-type levels of carbapenem activity brought about by the low-copy $S$. marcescens carR subclone pTON28 in the E. carotovora carR carI double mutant (compared with the lower, copy-number-dependent levels obtained in the $E$. carotovora carl mutants) support the idea of some interaction/competition between the OHHL-dependent $E$. carotovora CarR and the OHHL-independent $S$. marcescens CarR in an E. carotovora background (possibly forming mixed dimers/multimers or competing for the same target site).

Because there are multiple amino acid differences between the $E$. carotovora and $S$. marcescens CarR proteins, and as both exhibit strong amino acid identity in the putative autoinducer binding domain (Adar et al., 
1992), it is not at present obvious what the molecular basis for OHHL-independence is in the $S$. marcescens CarR. Perhaps mixing and matching of domains to form chimeric CarR proteins may allow the identification of the key residues involved in the release of CarR protein function from pheromone dependence.

\section{ACKNOWLEDGEMENTS}

This work was supported by the BBSRC. We thank D. Hodgson for plasmid pDAH330.

\section{REFERENCES}

Adar, Y. Y., Simaan, M. \& Ulitzur, S. (1992). Formation of the LuxR protein in the Vibrio fischeri lux system is controlled by the HtpR through the GroESL proteins. J Bacteriol 174, 7138-7143.

Azakami, H., Sugino, H., Iwata, N., Yamashita, M. \& Murooka, Y. (1993). moaR, a gene that encodes a positive regulator of the monoamine regulon in Klebsiella aerogenes. I Bacteriol 175, $6287-6292$.

Bainton, N. J. \& ten others (1992a). A general role for the lux autoinducer in bacterial cell signalling: control of antibiotic biosynthesis in Erwinia. Gene 116, 87-91.

Bainton, N. J., Stead, P., Chhabra, S. R., Bycroft, B. W., Salmond, G. P. C., Stewart, G. S. A. B. \& Williams, P. (1992b). N-(3-Oxohexanoyl)-L-homoserine lactone regulates carbapenem antibiotic production in Erwinia carotovora. Biochem J 288, 997-1004.

Bankier, A. T., Weston, K. M. \& Barrell, B. G. (1986). Random Cloning and Sequencing by the M13/Dideoxynucleotide Chain Termination Method. Cambridge: MRC Laboratory of Molecular Biology.

Beck von Bodman, S. \& Farrand, S. K. (1995). Capsular polysaccharide biosynthesis and pathogenicity in Erwinia stewartii require induction by an $\mathrm{N}$-acylhomoserine lactone autoinducer. $J$ Bacteriol 177, 5000-5008.

Bycroft, B. W., Maslen, C., Box, S. J., Brown, A. \& Tyler, J. W. (1988). The biosynthetic implications of acetate and glutamate incorporation into (3R,5R)-carbapenam-3-carboxylic acid and (5R)-carbapen-2-em-3-carboxylic acid by Serratia sp. I Antibiot 41, 1231-1242.

Choi, S. H. \& Greenberg, E. P. (1991). The C-terminal region of the Vibrio fischeri LuxR protein contains an inducer-independent lux gene activating domain. Proc Natl Acad Sci USA 88, 11115-11119.

Choi, S. H. \& Greenberg, E. P. (1992). Genetic dissection of DNA binding and luminescence gene activation by the Vibrio fischeri LuxR protein. J Bacteriol 174, 4064-4069.

Cubo, M. T., Economou, A., Murphy, G., Johnston, A. W. B. \& Downie, J. A. (1992). Molecular characterisation and regulation of the rhizosphere-expressed genes rhiABCR that can influence nodulation by Rhizobium leguminosarum biovar viciae. $J$ Bacteriol 174, 4026-4035.

Ellard, F. M., Cabello, A. \& Salmond, G. P. C. (1989). Bacteriophage lambda-mediated transposon mutagenesis of phytopathogenic and epiphytic Erwinia species is strain dependent. Mol Gen Genet 218, 491-498.

Forbes, K. J. \& Perombelon, M. C. M. (1985). Chromosomal mapping of Erwinia carotovora subspecies carotovora with the IncP plasmid R68:: Mu. J Bacteriol 164, 1110-1116.

Fuqua, W. C., Winans, S. C. \& Greenberg, E. P. (1994). Quorum sensing in bacteria: the LuxR-LuxI family of cell densityresponsive transcriptional regulators. J Bacteriol 176, 269-275.
Gambello, M. J. \& Iglewski, B. H. (1991). Cloning and characterisation of the Pseudomonas aeruginosa las $\mathrm{R}$ gene, a trancriptional activator of elastase expression. J Bacteriol 173, 3000-3009.

Hanahan, D. (1983). Studies on transformation of E. coli with plasmids. J Mol Biol 166, 557-580.

Hopwood, D. A., Chater, K. F. \& Bibb, M. J. (1995). Genetics of antibiotic production in Streptomyces coelicolor A3(2), a model streptomycete. Biotechnology 28, 65-102.

Gray, K. M. \& Greenberg, E. P. (1992). Sequencing and analysis of $l u x R$ and $l u x I$, the luminescence regulatory genes from the squid light organ symbiont Vibrio fischeri ES114. Mol Marine Biol Biotechnol 1, 414 419.

Imada, A., Kitato, K., Kintaka, K., Muroi, M. \& Asai, M. (1981). Sulphacecin and isosulphazecin, novel $\beta$-lactam antibiotics of bacterial origin. Nature 289, 590-591.

Jones, S. \& 12 others (1993). The lux autoinducer regulates the production of exoenzyme virulence determinants in Erwinia carotovora and Pseudomanas aeruginosa. EMBO J 12, 24772482.

Kahan, F. M., Kropp, H., Sundelof, J. G. \& Birnbaum, J. (1983). Theinamycin: development of imipenem-cilastatin. J Antimicrob Chemother 12, 1-35.

Krebs, M. P. \& Reznikoff, W. S. (1988). Use of a $\operatorname{Tn} 5$ derivative that creates lacZ translational fusions to obtain a transposition mutant. Gene 63, 277-285.

Kropp, H., Sundelof, J. G., Kahan, J. S., Kahan, F. M. \& Birnbaum, J. (1980). MK0787 ( $N$-formimidoyl thienamycin): evaluation of in vitro and in vivo activities. Antimicrob Agents Chemother 17, 993-1000.

Kropp, H., Gerkens, L., Sundelof, J. G. \& Kahan, F. M. (1985). Antibacterial activity of imipenem: the first thienamycin antibiotic. Rev Infect Diseases 7, 389-410.

Labia, R., Morand, A. \& Guionie, M. (1986). $\beta$-Lactamase stability of imipenem. J Antimicrob Chemother 18, 1-8.

McGowan, S. \& nine others (1995). Carbapenem antibiotic production in Erwinia carotovora is regulated by CarR, a homologue of the LuxR transcriptional activator. Microbiology 141, 541-550.

McGowan, S., Sebaihia, M., Porter, L. E., Stewart, G. S. A. B., Williams, P., Bycroft, B. \& Salmond, G. P. C. (1996). Analysis of bacterial carbapenem antibiotic production genes reveals a novel $\beta$-lactam biosynthesis pathway. Mol Microbiol 22, 415-426.

Messing, J., Gronenborn, B., Muller-Hill, B. \& Hofschneider, P. (1977). Filamentous coliphage $M 13$ as a cloning vehicle: insertion of a HindII fragment of the lac regulatory region in M13 replicative form in vitro. Proc Natl Acad Sci USA 74, 3642-3646. Miller, J. H. (1972). Experiments in Molecular Genetics. Cold Spring Harbor, NY: Cold Spring Harbor Laboratory.

Morrison, D. A. (1966). Prodigiosin synthesis in mutants of Serratia marcescens. J Bacteriol 91, 1599-1603.

Mulholland, V. \& Salmond, G. P. C. (1995). Use of coliphage $\lambda$ and other bacteriophages for molecular genetic analysis of Erwinia and related Gram-negative bacteria. Methods Mol Genet 6, $439-454$.

Oschner, U. L., Koch, A., Fiechter, A. \& Reiser, J. (1994). Isolation and characterisation of a regulatory gene affecting rhamnolipid biosurfactant synthesis in Pseudomonas aeruginosa. J Bacteriol 176, 2044-2054.

Parker, W. L., Rathnum, M. L., Wells, J. S., Jr, Trejo, W. H., Principe, P. A. \& Sykes, R. B. (1982). SQ 27860, a simple carbapenem 
produced by species of Serratia and Erwinia. J Antibiot 35, 653-660.

Passador, L., Cook, J. M., Gambello, M. J., Rust, L. \& Iglewski, B. H. (1993). Expression of Pseudomonas aeruginosa virulence genes requires cell-to-cell communication. Science 260, 11271130.

Pearson, J. P., Gray, K. M., Passador, L., Tucker, K. D., Eberhard, A., Iglewski, B. H. \& Greenberg, E. P. (1994). Structure of the autoinducer required for expression of Pseudomonas aeruginosa virulence genes. Proc Natl Acad Sci USA 91, 197-201.

Pierson, L. S., III, Keppenne, V. D. \& Wood, D. W. (1994). Phenazine antibiotic biosynthesis in Pseudomonas aeruginosa $30-84$ is regulated by $\mathrm{PhzR}$ in response to cell density. J Bacteriol 176, 3966-3974.

Piper, K. R., Beck von Bodman, S. \& Farrand, S. K. (1993). Conjugation factor of Agrobacterium tumefaciens regulates $\mathrm{Ti}$ plasmid transfer by autoinduction. Nature 362, 448-450.

Salmond, G. P. C., Bycroft, B., Stewart, G. S. A. B. \& Williams, P. (1995). The bacterial enigma: cracking the code of cell-cell communication. Mol Microbiol 16, 615-624.

Sanger, F., Nicklen, S. \& Coulsen, A. R. (1977). DNA sequencing with chain terminating inhibitors. Proc Natl Acad Sci USA 74, 5463-5467.

Selvaraj, G., Fong, Y. C. \& lyer, V. N. (1984). A portable DNA sequence carrying the cohesive site (cos) of bacteriophage $\lambda$ and the $m o b$ (mobilization) region of the broad-host-range plasmid RK2: a module for the construction of new cosmids. Gene 32, 235-241.

Sykes, R. B. \& 12 others (1981). Monocyclic $\beta$-lactam antibiotics produced by bacteria. Nature 291, 489-491.

Tabor, S. \& Richardson, C. C. (1985). A bacteriophage T7 RNA polymerase/promoter system for controlled exclusive expression of specific genes. Proc Natl Acad Sci USA 82, 1074-1078.

Throup, J. P., Camara, M., Briggs, G. S., Winson, M. K., Chhabra, R., Bycroft, B. W., Williams, P. \& Stewart, G. S. A. B. (1995). Characterisation of the $y e n I / y e n R$ locus from Yersinia entero- colitica mediating the synthesis of $2 \mathrm{~N}$-acylhomoserine lactone signal molecules. Mol Microbiol 17, 345-356.

Toth, I. K., Perombelom, M. C. M. \& Salmond, G. P. C. (1993). Bacteriophage $\phi \mathrm{KP}$ mediated generalised transduction in Erwinia carotovora subspecies carotovora. J Gen Microbiol 139, 27052709.

Tsao, S. W., Rudd, B. A. M., He, X. G., Chang, C. \& Floss, H. G. (1985). Identification of a red pigment from Streptomyces coelicolor $\mathrm{A} 3(2)$ as a mixture of prodigiosin derivatives. $J$ Antibiotics 38, 128-131.

Vollenweider, H. J., Fiandt, M., Rosenvold, E. C. \& Szybalski, W. (1980). Packaging of plasmid DNA containing the cohesive ends of coliphage lambda. Gene 9, 171-174.

Wang, X., de Boer, P. A. J. \& Rothfield, L. I. (1991). A factor that positively regulates cell division by activating transcription of the major cluster of essential cell division genes of E. coli. EMBO J10, 3363-3372.

White, F. F., Klee, H. J. \& Nester, E. W. (1983). In vivo packaging of cosmids in transposon mediated mutagenesis. J Bacteriol 153, 1075-1078.

Williamson, J. M. (1986). The biosynthesis of theinomycin and related carbapenems. CRC Crit Rev Biotechnol 4, 111-131.

Wilmes-Riesenberg, M. R. \& Wanner, B. L. (1992). TnphoA and TnphoA' elements for making and switching fusions for study of transcription, translation and cell surface localisation. J Bacteriol 174, 4558-4575.

Wood, D.W. \& Peirson, L. S., III (1996). The phzI gene of Pseudomonas aureofaciens $30-84$ is responsible for the production of a diffusible signal required for phenazine antibiotic production. Gene 168, 49-53.

Zhang, L., Murphy, P. J., Kerr, A. \& Tate, M. E. (1993). Agrobacterium conjugation and gene regulation by $N$-acyl-L-homoserine lactones. Nature 362, 446-448.

Received 25 April 1997; revised 5 September 1997; accepted 15 September 1997. 